\title{
Identification of Triterpenoids from Schefflera systyla, Odontadenia puncticulosa and Conostegia speciosa and In Depth Investigation of Their in vitro and in vivo Antifungal Activities
}

\author{
Quentin Favre-Godal, ${ }^{a, \#}$ Stephane Dorsaz, ${ }^{b, \#}$ Laurence Marcourt, ${ }^{a}$ Valentina Bertini, ${ }^{a}$ \\ Emmanuelle Dormia, ${ }^{a}$ Emilie Michellod,${ }^{c}$ Francine Voinesco,${ }^{c}$ Mahabir Gupta ${ }^{d}{ }^{K a t i a}$ \\ Gindro, ${ }^{c}$ Dominique Sanglard, ${ }^{b}$ Emerson F. Queiroz $z^{a}$ and Jean-Luc Wolfender*,a \\ ${ }^{a}$ School of Pharmaceutical Sciences, EPGL, University of Geneva, University of Lausanne, CMU, \\ Rue Michel-Servet 1, CH-1211 Geneva, Switzerland \\ ${ }^{b}$ Institute of Microbiology, University of Lausanne and University Hospital Center, \\ Rue du Bugnon 48, CH-1011 Lausanne, Switzerland \\ 'Agroscope, Institute for Plant Production Sciences (IPS), Mycology and Biotechnology, \\ Route de Duiller 50, P.O. Box 1012, CH-1260 Nyon, Switzerland \\ ${ }^{d}$ Center of Pharmacognostic Research on Panamanian Flora (CIFLORPAN), College of Pharmacy, \\ University of Panama, P.O. Box 0824-00172, Panama City, Panama
}

\begin{abstract}
As a part of a broad screening of antifungal agents from plant origin, crude extracts from Panamanian plants having related types of constituents displayed significant activities in an agar overlay thin layer chromatography assay against a susceptible strain of Candida albicans. These were the methanolic extract of the leaves of Schefflera systyla and Odontadenia puncticulosa and of the stems of Conostegia speciosa, that are species not previously investigated from a phytochemical viewpoint. For all plants, high-performance liquid chromatography (HPLC) antifungal activity based profiling allowed the rapid localization of antifungal agents that were further obtained by targeted isolation procedure by semi-preparative HPLC or medium pressure liquid chromatography (MPLC) after LC gradient transfer. Different hederagenin saponins and one aglycone were found to be responsible for the antifungal activities of the extracts. Alpha-hederin was the antifungal of $S$. systyla, pulsatilla saponin D and $3 \beta-\mathrm{O}-[\beta-\mathrm{D}$-xylopyranosyl- $(1 \rightarrow 3)-\alpha-\mathrm{L}-$ rhamnopyranosyl$(1 \rightarrow 2)$-[ $\beta$-D-glucopyranosyl-(1 $\rightarrow 4)]-\alpha$-L-arabinopyranosylhederagenin of $O$. puncticulos $a$ and arjunolic acid of $C$. speciosa. Their minimal inhibitory concentration (MIC) against planktonic and biofilm cells of $C$. albicans were determined. Alpha-hederin was the most potent compound with a MIC of $4 \mu \mathrm{g} \mathrm{mL}{ }^{-1}$. Structurally related compounds (hederagenin, medicagenic acid 3-O- $\beta$-D-glucopyranoside and medicagenic acid) were used as standards and tested for comparison purposes. In order to better estimate the potential of these triterpenoids as antifungal agents, their cytological effects on $C$. albicans were determined by transmission electron microscopy (TEM) and the in vivo activity of alpha-hederin, medicagenic acid 3-O- $\beta$-D-glucopyranoside and medicagenic acid was evaluated for the first time in the Galleria mellonella larvae model.
\end{abstract}

Keywords: triterpenoids, microfractionation, antifungal, Candida species, Galleria mellonella

\section{Introduction}

Fungal infections have recently increased worldwide and cause high morbidity and mortality rates among different groups of human patients. ${ }^{1}$ The development

*e-mail: jean-luc.wolfender@unige.ch

\#These authors contributed equally to this work. of drug resistance in fungal pathogens compromises the efficacy of the limited number of therapeutic agents. ${ }^{2}$

The main fungal opportunistic human pathogens are Candida spp., and among them, the most common species is Candida albicans. ${ }^{3}$ In the USA, Candida species are the fourth cause of nosocomial bloodstream infections. ${ }^{4,5}$ Over 400,000 candidiasis infections are declared per year worldwide. ${ }^{6}$ Moreover, Candida species display a tendency 
to grow as biofilms on implanted medical devices such as a central venous catheter. ${ }^{7}$ Biofilm cells exhibit up to a 1,000-fold increase in resistance as compared to their planktonic counterparts ${ }^{8}$ which may contribute to therapeutic failures. ${ }^{9}$ These facts make urgent the need to identify new chemical entities that may lead to the discovery of new antimicrobial agents against planktonic cells and/or biofilms with higher efficiency, lower toxicity, or with new modes of action. ${ }^{10}$

In this context, plants secondary metabolites can be of interest. Many plant extracts have indeed been reported for their antifungal activity but only a small part had their active principles identified. ${ }^{11}$ Terpenes, alkaloids, steroids and phenolic compounds are known to be responsible for antifungal properties in the plant kingdom. ${ }^{12}$

In order to identify rapidly antifungals from plant sources, we have recently developed a strategy for the early localization and efficient identification of antifungal compounds in complex crude extracts. ${ }^{13}$ Using this approach more than 150 species and 400 extracts with different polarities have been evaluated. Among all extracts, those of three plants that exhibited significant activities against a susceptible strain of $C$. albicans were selected. This $C$. albicans isolate is used as a sensitive tool to detect bioactive secondary metabolites. ${ }^{13}$ These plants (Schefflera systyla (Donn. Sm.) R.Vig Araliaceae, Odontadenia puncticulosa (Rich.) Pulle Apocynaceae, and Conostegia speciosa (Naudin) Melastomataceae) were all obtained from Panama and have not been previously investigated from a phytochemical viewpoint.

S. systyla (Araliaceae) is widespread in sub-tropical and tropical regions in Asia and Central America. ${ }^{14}$ Several species of the Schefflera genus have been investigated and were reported to contain antiviral caffeoylquinic acids, triterpenoids and oligosaccharides. ${ }^{15,16} \mathrm{O}$. puncticulosa (Apocynaceae) belongs to the Odontadenia genus that contains only 20 species widespread from Mexico to Bolivia. ${ }^{17}$ O. puncticulosa has been traditionally used in South America to treat rubeola, digestive disorders and side effects caused by snakebite. ${ }^{18-20}$ Only $O$. macrantha has been chemically studied with the identification of a new cytotoxic limonoid and two triterpenoids. ${ }^{21}$ The Conostegia genus (Melastomataceae) contains 42 species and none of these species have been investigated from a phytochemical viewpoint. ${ }^{22}$ The present study illustrates the isolation of the antifungal principles of the selected species and an in depth evaluation of their bioactivity profiles.

\section{Results and Discussion}

The minimal inhibitory quantities (MIQ) measured by bioautography without elution at the screening step were 15 and $20 \mu \mathrm{g}$ for the S. systyla and O. puncticulosa extracts, respectively. Interestingly, for the extract of $C$. speciosa the antifungal activity was observed only when the extract was separated on the plate and therefore no MIQ values could be determined. For $S$. systyla and $O$. puncticulosa the active zones could not be correlated to an UV detectable spot in the high-performance thin-layer chromatography-ultraviolet (HPTLC-UV) analysis suggesting the presence of non-UV active compounds (Figure 1A; Figure S1, Supplementary Information).

HPLC-PDA-ELSD metabolite profiling of the active extracts

Each extract was analysed by HPLC-photo diode arrayevaporative light scattering detector (PDA-ELSD) using a reverse phase $\mathrm{C}_{18}$ column. Since the HPTLC analysis suggested that the active compounds did not possess an UV chromophore, ELSD was used in order to detect these compounds. The comparison between the PDA and ELSD traces showed the presence of major compounds only detected with ELSD (Figures 1B and S1).

HPLC antifungal based profiling by at-line microfractionation and bioautography

In order to localize and isolate the compounds responsible for the antifungal activities, the active extracts were fractionated by semi-preparative HPLC on a $10 \mathrm{~mm}$ i.d. $\mathrm{C}_{18}$ column. The gradient time and flow rate for this micro-fractionation were adapted from the analytical HPLC using a gradient transfer method..$^{23-25}$ This procedure provided a satisfactory separation of the crude extract constituents, and most microfractions corresponded to single LC peaks. The microfractions obtained in this step were dried and submitted to the antifungal bioautography assay with the susceptible strain of $C$. albicans without any further elution step.

Following this procedure the methanolic extract of $S$. systyla $(25 \mathrm{mg})$ yielded 42 microfractions. The antifungal activity was found in three consecutive fractions, corresponding to the major LC peak detected by ELSD (Figure 1). Similarly the extract of $O$. puncticulosa yielded 57 fractions and two presented antifungal activities corresponding to a minor LC-peak in the UV chromatogram (Figure S1, Supplementary Information). The extract of C. speciosa, $39 \mathrm{mg}$ yielded 50 fractions. Among these fractions, three presented antifungal activity (Figure S1, Supplementary Information). The procedure provided thus a rapid and efficient way to rapidly localize and isolate the bioactive LC-peaks of interest. 
A.

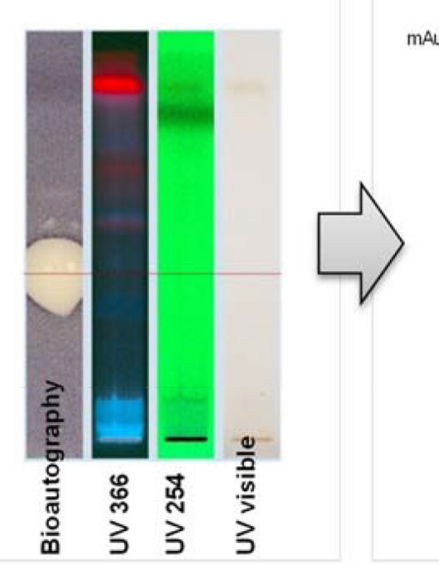

B.

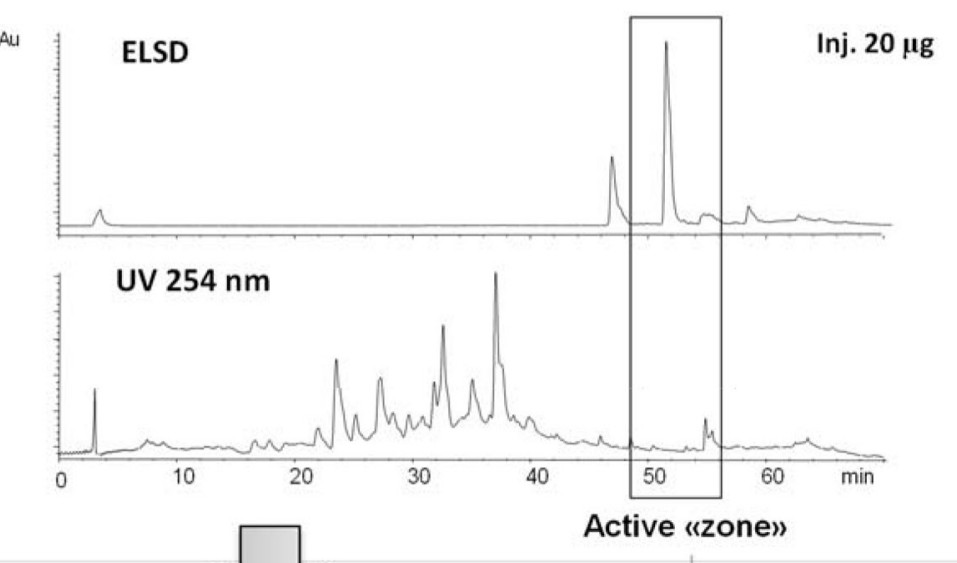

c.

C.

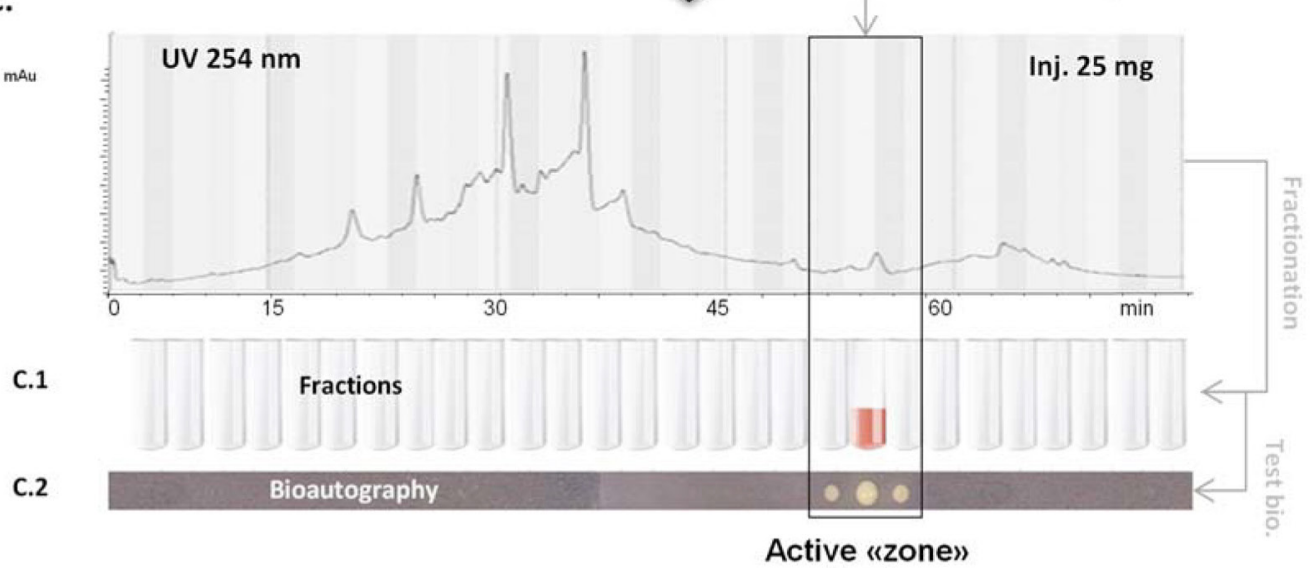

E.
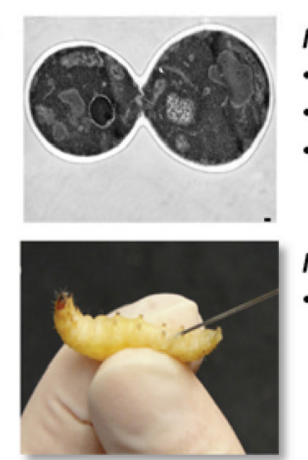

In vitro assays

- MIQ

- MIC

- Biofilm inhibition

In vivo assay

- G. mellanolela
D.<smiles>C1CC2CCC1C2</smiles>

Figure 1. (A) HPTLC analysis and antifungal bioautographic of the methanolic extract of the leaves of Schefflera systyla; (B) HPLC-PDA-ELSD analysis of the active extract; (C) HPLC-activity profiling by microfractionation at the semi preparative (C1) followed with an agar overlay bioautographic against the mutant strain of $C$. albicans; (D) NMR and HRMS analyses of the active fraction; (E) in vivo and in vitro antifungal activity against the wild-type strain.

Identification of the active compounds

Nuclear magnetic resonance (NMR) and high-resolution mass spectrometry (HRMS) analyses were performed on each active microfractions (Figures 1 and S1). The active compound of $S$. systyla was identified as the triterpenoid saponin $(\alpha)$-hederin $(\mathbf{1})$, which has been already described in some species of the Schefflera genus. ${ }^{26}$ Similarly the active principle of $C$. speciosa was identified as arjunolic acid (4) which was previously isolated from Terminalia arjuna (Figure 2). 27,28

The NMR and MS analyses of the first fraction of $O$. puncticulosa allowed the identification of the active pulsatilla saponin $\mathrm{D}$ (2), a compound previously described in Pulsatilla cemum and P. koreana. ${ }^{29}$ The structure of the compound present in the second active fraction could 
not be achieved due to the small amount available. Its targeted isolation was performed by medium pressure liquid chromatography (MPLC) after direct transfer of the analytical HPLC conditions to MPLC from $4 \mathrm{~g}$ of crude dichloromethane extract according to a previously reported protocol..$^{30}$ This yielded $33.8 \mathrm{mg}$ of the minor active principle that was identified as $3 \beta-O-[\beta-D-x y l o p y r a n o s y l-(1 \rightarrow 3)]-\alpha-$ L-rhamnopyranosyl-( $1 \rightarrow 2)$-[ $\beta$-D-glucopyranosyl- $(1 \rightarrow 4)]-$

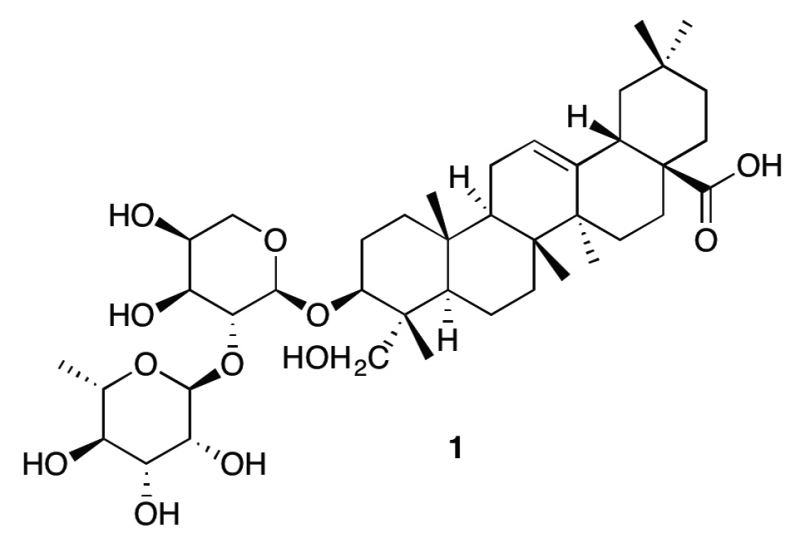

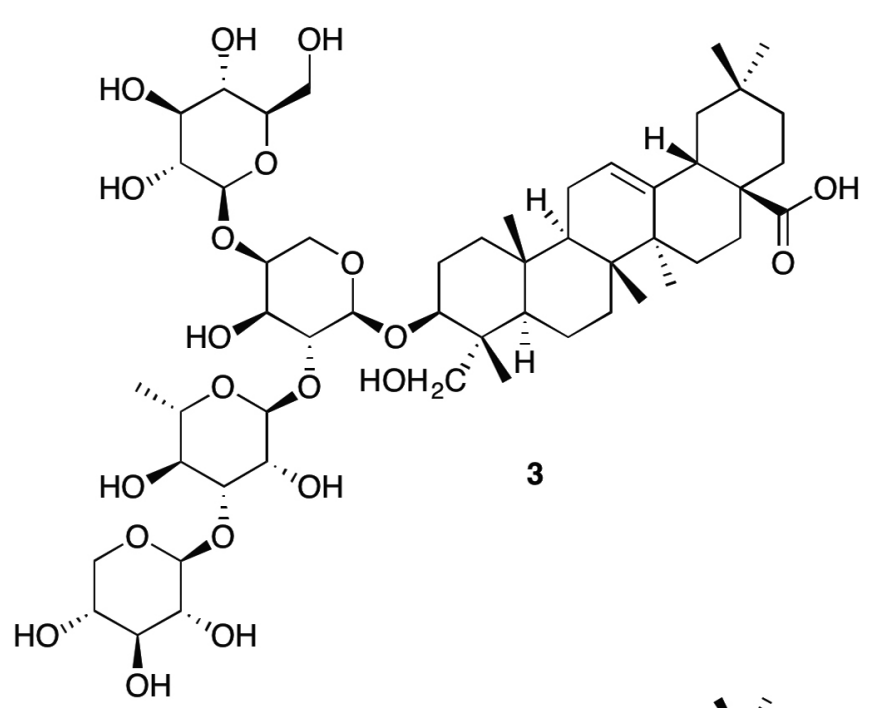

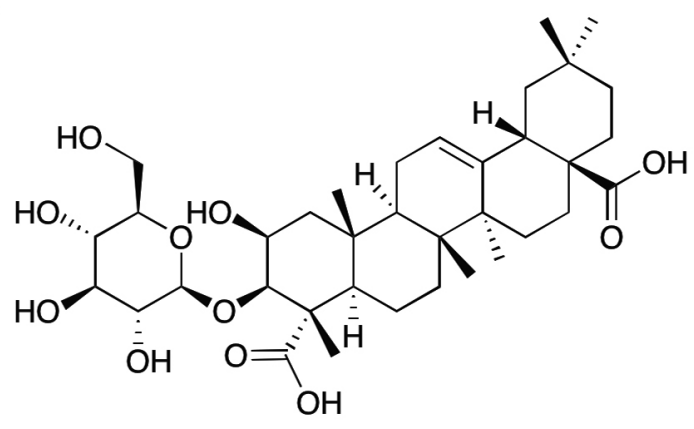

$\alpha$-L-arabinopyranosylhederagenin (3), a saponin previously described on Anemone taipaiensis (Figure 2). ${ }^{31}$

\section{Antifungal activities of the isolated triterpenoids}

The isolated compounds were tested against wildtype $C$. albicans cells (CAF2-1) with both bioautography and standard broth dilution susceptibility assays. ${ }^{13}$

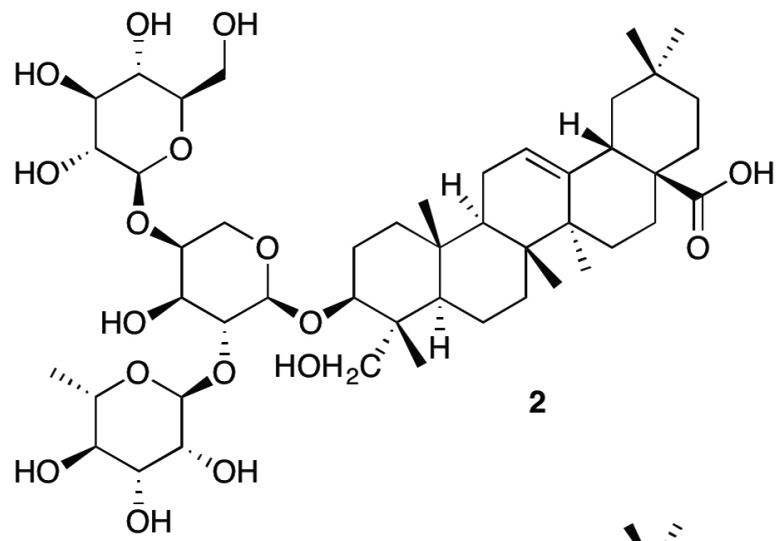<smiles>CC1(C)CC[C@]2(C(=O)O)CC[C@]3(C)C(=CC[C@@H]4[C@]3(C)CC[C@]3(C)[C@H](CO)[C@@H](O)[C@H](O)C[C@]43C)[C@@H]2C1</smiles>

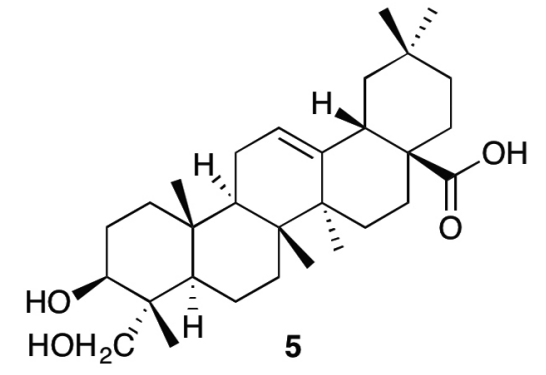

Figure 2. Structures of the triterpenoids isolated (1-4) and commercially obtained (5-7). 
Compound $\mathbf{1}$ was the most active with a MIQ value of $2.5 \mu \mathrm{g}$ with bioautography and a minimal inhibitory concentration (MIC) of $4 \mu \mathrm{g} \mathrm{mL}{ }^{-1}$ against the susceptible strain (DSY2621) (Table 1). Antifungal activities against Microsporum canis, Coccidioides immitis, Trichophyton mentagrophytes, Cryptococcus neoformans and $C$. albicans of this compound have been previously described in the literature. ${ }^{32}$ Compound $\mathbf{2}$ was active against C. albicans with a MIQ of $15 \mu \mathrm{g}$ and a MIC of $8 \mu \mathrm{g} \mathrm{mL}^{-1}$, which is consistent with published data indicating an antifungal activity at similar concentration range for this compound. ${ }^{33}$ Compound $\mathbf{3}$ was less active with a MIQ equal to $20 \mu \mathrm{g}$ and a MIC equal to $16 \mu \mathrm{gL}^{-1}$ and it was not previously been reported for its antifungal activity. No activity was detected using broth dilution susceptibility assay (MIC $>32 \mu \mathrm{g} \mathrm{mL}^{-1}$ ) for $\mathbf{4}$ despite the MIQ of $10 \mu \mathrm{g}$. This compound was previously described as active against C. albicans at higher concentration $\left(50 \mu \mathrm{g} \mathrm{mL}^{-1}\right) .^{34}$

All compounds were then evaluated against different Candida species (C. glabrata, C. krusei, C. tropicalis and $C$. parapsilosis) in broth dilution assays in order to determine the bioactivity profile against various strains of the genus (Table 2). All compounds showing activities against $C$. albicans exhibited similar activities against the different species tested.

As most C. albicans cells do not exist as free planktonic cells but rather as groups of organized cells called biofilms that display increase resistance to antifungal drugs, ${ }^{35}$ compounds were tested with mature C. albicans biofilms according to standard protocol. ${ }^{36}$ Compounds $\mathbf{1}$ and $\mathbf{2}$ inhibited biofilm metabolic activity at the highest concentration tested $\left(50 \mu \mathrm{g} \mathrm{mL}^{-1}\right)$ whereas compounds 3 and $\mathbf{4}$ did not have any effect.

In order to verify the importance of the sugars moiety for the antifungal activity, the common aglycone of compounds $\mathbf{1}, \mathbf{2}$ and $\mathbf{3}$, named hederagenin (5), was commercially obtained and evaluated in the antifungal assays. This compound was found completely inactive. A comparison of the activity between 1, 2, and $\mathbf{3}$ suggests that the antifungal activity decreases as the number of sugars present in the molecule increases. According to MIC values obtained, it seems clear that

Table 1. Bioautography and broth dilution assay of the isolated compounds and reference compound

\begin{tabular}{|c|c|c|c|}
\hline \multirow{2}{*}{ Compound } & \multicolumn{2}{|c|}{ Bioautography assay } & \multirow{2}{*}{$\begin{array}{c}\text { Dilution assay } \\
\text { C. albicans }(\mathrm{CAF} 2-1)^{\mathrm{b}} /\left(\mu \mathrm{g} \mathrm{mL}^{-1}\right)\end{array}$} \\
\hline & C. albicans (DSY2621) / $\mu \mathrm{g}$ & C. albicans $(\mathrm{CAF} 2-1)^{\mathrm{a}} / \mu \mathrm{g}$ & \\
\hline 1 & 1.5 & 2.5 & 4 \\
\hline 2 & 3.2 & 15 & 8 \\
\hline 3 & 10 & 20 & 16 \\
\hline 4 & 10 & 10 & d \\
\hline 5 & d & d & d \\
\hline 6 & 3 & 5 & 2 \\
\hline 7 & 3 & 9 & 2 \\
\hline Miconazole $^{c}$ & 0.0006 & 0.005 & 0.0156 \\
\hline
\end{tabular}

${ }^{\mathrm{a}}$ Minimum amount required for antifungal activity on TLC plate; ${ }^{\mathrm{b}}$ minimum inhibitory concentration (MIC); creference compound; ${ }^{\text {inactive: }}$ MIQ $>20 \mathrm{\mu g}$; MIC $>32 \mu \mathrm{g} \mathrm{mL}{ }^{-1}$. MIQ: minimal inhibitory quantities.

Table 2. Broth dilution assay of the isolated compounds and reference compound on Candida species

\begin{tabular}{|c|c|c|c|c|}
\hline \multirow{2}{*}{ Compound } & \multicolumn{4}{|c|}{ Dilution assay / $\left(\mu \mathrm{g} \mathrm{mL}^{-1}\right)$} \\
\hline & C. glabrata (DSY562) ${ }^{\mathrm{a}}$ & C. krusei (DSY471)a & C. tropicalis (DSY472) ${ }^{\mathrm{a}}$ & C. parapsilosis (DSY473) \\
\hline 1 & 2 & 2 & 4 & 4 \\
\hline 2 & 8 & 8 & 8 & 8 \\
\hline 3 & 8 & 16 & 16 & 16 \\
\hline 4 & c & c & c & c \\
\hline 5 & c & $\mathrm{c}$ & c & $\mathrm{c}$ \\
\hline 6 & 2 & 2 & 2 & 2 \\
\hline 7 & 1 & 1 & 2 & 1 \\
\hline Caspofungin ${ }^{\mathrm{b}}$ & 0.0625 & 0.125 & 0.5 & 1 \\
\hline
\end{tabular}

${ }^{\mathrm{a}}$ Minimum inhibitory concentration (MIC); ${ }^{\mathrm{b}}$ reference compound; cinactive: $\mathrm{MIC}>32 \mu \mathrm{g} \mathrm{mL}{ }^{-1}$. 
one or two sugars at $\mathrm{C}-3$ of the aglycone hederagenin are ideal for the antifungal activity. Indeed, some monodesmosidic glycosides (with only one sugar chain at C-3) of hederagenin have been showed to be active against $C$. albicans whereas their bidesmosides forms (with an additional sugar chain at C-28) were inactive. ${ }^{32}$ In addition, it has been described that rhamnosyl-arabinosyl moiety at C-3 increased the anti-Candida activity of hederagenin glycosides compared to other sugar chain. ${ }^{37}$ It might be due to variances in the molecular conformation of the saponins that would induce differential membrane curvature and membrane permeabilization. ${ }^{38}$

In order to compare the activities and cytological effects of the isolated compounds, one additional antifungal saponin, medicagenic acid 3-O- $\beta$-D-glucopyranoside (6) and its aglycone, medicagenic acid (7) were included in the different biological assays. In the broth dilution assay, 6 and 7 showed as expected strong antifungal activity with MIC value of $2 \mu \mathrm{g} \mathrm{mL} \mathrm{m}^{-1}$. The activity spectrum was similar to the isolated compound. The MIC values were 1 or $2 \mu \mathrm{g} \mathrm{mL} \mathrm{m}^{-1}$ on every Candida species tested. Compound 6 has been reported to have antifungal effects against Trichoderma viride, Aspergillus niger and against several medically important yeasts such as C. albicans. ${ }^{39-42}$ Its mode of action against Saccharomyces cerevisiae seems to be different from that described for polyene antibiotics. ${ }^{43}$ 7 has reported antifungal activities against $C$. tropicalis, C. albicans, Blastomyces capitatus and Saccharomyces cerevisiae. ${ }^{44}$ As compared to other saponins aglycones that are inactive, the low MIC value of 7 might be rationalised by the presence of the carboxylic acid function in position 4 that gives polar properties to the molecules.

\section{Examination of cytological alterations caused by antifungal compounds using transmission electron microscopy evaluation (TEM)}

Although interference with the integrity of biological membranes is the main effect of saponin activities, saponins are not limited to this type of action. As a matter of fact, saponins show significant haemolytic activity. ${ }^{45}$ Solely based on their structures it is difficult to predict their activities. To get a better understanding of the action of isolated saponins, the cytological effects of the most active compounds on wild type strain of $C$. albicans were investigated by transmission electron microscopy analysis (TEM). Yeast were grown on YNB (yeast nitrogen base) medium at $\mathrm{pH} 4.6$ and treated with these compounds at the MIC concentration including controls. Non-treated C. albicans cells showed intact cell walls, cell membranes and organelles, such as mitochondria, nuclei and nuclear membranes. A high number of ribosomal particles could be observed across the cytoplasm. Contrary to negative controls (Figures 3A and 3B), C. albicans cells treated by $\mathbf{1}, \mathbf{2}$, and $\mathbf{3}$ exhibited alterations of the cell wall architecture with the appearance of dark disorganized material into the cell wall space (Figures 3C and 3D). This is consistent with previous studies on the cytotoxic effect of $(\alpha)$-hederin on C. albicans cells. ${ }^{46}$ Important disorganization, darkening and retraction of the cytoplasmic content were observed, where mitochondria, nucleus, nuclear membranes, Golgi apparatus and ribosomes were not visible. In addition, the plasma membrane exhibited significant degradation and several breakage zones.

Yeast cells treated with $\mathbf{6}$ showed similar effects to those exposed to $\mathbf{2}$ with an important retraction and distortion of the plasma membrane and a thickening of the cell wall (Figures 3E and 3F). These results are consistent with the cytotoxic effects observed on plant cell suspension cultures. ${ }^{47}$ Contrary to what was shown after treatment with the reference drug miconazole, ${ }^{13}$ no accumulation of lipid-like bodies was observed in vacuoles, neither highly contrasted membranes, with the exception of dark material in the parietal zone of cell walls.

\section{In vivo assays using the Galleria mellonella model}

Compounds 1, 6 and 7 were selected for further investigation to determine their in vivo activity on the G. mellonella infection model. ${ }^{13}$ This in vivo model is used to study the virulence of microbial pathogens and the efficacy of antimicrobial agents using insect larvae. Several studies have demonstrated the efficacy of known antifungal agents in this model for Candida infection. ${ }^{48}$ A direct correlation has been demonstrated between the virulence of $C$. albicans in murine and wax moth larvae models of infection. ${ }^{49}$ Moreover, this model is inexpensive and easy to handle.

To assess the potential toxicity of $\mathbf{1}$, several doses were first administered through the last pro-leg and the survival of the larva was monitored. Unexpectedly, larvae exhibited an important and significant increase in mortality from concentrations equal or superior to $50 \mathrm{mg} \mathrm{kg}^{-1}(\mathrm{n}=10$, log-rank (Mantel-Cox) test, $\mathrm{p}<0.0001$ ) and thus, the in vivo efficacy was tested at lower concentrations. The larvae were infected with wild-type $C$. albicans and one hour post-infection 1 was administered at $25 \mathrm{mg} \mathrm{kg}^{-1}$. The survival rate was monitored for eight days. While fluconazole, a well-known antifungal azole drug, caused a dramatic increase in the survival rate of larvae compared to the infected controls (Mantel-Cox test, $\mathrm{p}<0.0001$ ), 

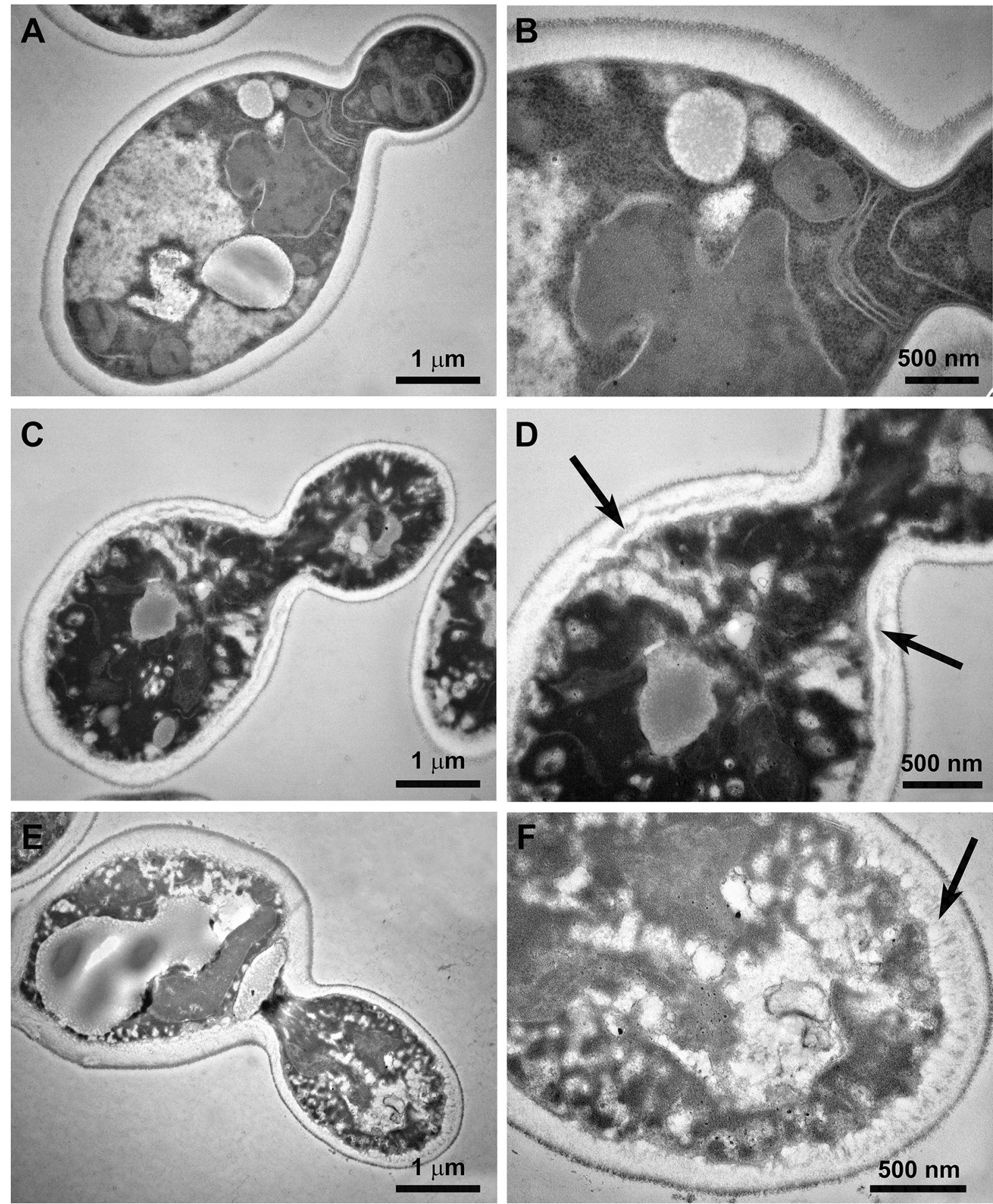

Figure 3. Ultrastructure of C. albicans strain CAF2-1 at 18 hours after treatment with compound 2 or compound $\mathbf{6}$ as observed by transmission electron microscopy. (A) Control without treatment; (B) detail of (A) showing intact organelles and membrane systems and a rich ribosomes cytoplasmic content; (C) after treatment with compound 2 at $8 \mu \mathrm{g} \mathrm{mL}-1$; (D) detail of (C) showing altered cell wall structure (arrows) and cytoplasmic destructuration and darkening; (E) after treatment with compound 6 at $2 \mu \mathrm{g} \mathrm{mL}{ }^{-1}$; (F) detail of E showing alerted cell wall structure (arrow) and cytoplasmic destructuring.

1 showed no significant effects on survival as compared to controls (Mantel-Cox test, $\mathrm{p}>0.05$ ) (data not shown). Contrary to $\mathbf{1}$, compounds $\mathbf{6}$ and $\mathbf{7}$ did not show toxicity effect on larvae up to $50 \mathrm{mg} \mathrm{kg}^{-1}$, however, similarly to $\mathbf{1}$, and even at higher doses, they did not exhibit significant effect on survival as compared to non-treated controls (Mantel-Cox test, $\mathrm{p}>0.05$ ).

\section{Conclusions}

HPLC activity-based metabolite profiling enable a rapid and efficient identification of triterpenoids from Panamanian plants not previously investigated for their bioactive constituents. From a chemotaxonomic viewpoint, the presence of these compounds are in agreement with 
previous studies on the Schefflera, Odontadenia and Conostegia genus. ${ }^{50}$

Among isolates compounds, $(\alpha)$-hederin (1) was the most interesting by its large spectral profile against Candida species and its activity against biofilms. It induces modifications of cellular contents and alterations of cell envelope with degradation and death of the yeast cells. ${ }^{46} \mathrm{~A}$ recent study demonstrated that the haploinsufficiency profile of $(\alpha)$-hederin was similar to that reported for drugs such as caspofungin that inhibit synthesis of the fungal cell wall. ${ }^{51}$ It has been shown that $\mathbf{1}$ daily orally administrated in mice infected with C. albicans was able to cure the mice at $100 \mathrm{mg} \mathrm{kg}^{-1}$ over 10 days. ${ }^{52}$ In our assay $(\alpha)$-hederin did not show antifungal activity in G. mellonella, suggesting the limitation of this assay for such class of compounds. The absence of in vivo antifungal activity of $\mathbf{1}$ in G. mellonella could be explained by the poor membrane permeability of the triterpene glycosides due to its large molecular mass (>500 Da), high hydrogen-bonding capacity $(>12)$ and high molecular flexibility $(>10) . .^{53}$

Saponins are known to possess many biological activities such as haemolytic, antiviral, fungicidal, molluscicidal or cytotoxic activities, partially due to their interaction with the cell membrane..$^{50,54}$ Recently, some saponins have shown in vivo antifungal activity comparable to amphotericin B against Candida species in the C. elegans nematode assay. ${ }^{55}$ In this work no hemolysis of erythrocytes (common cause of toxicity) was observed suggesting that some saponins have preference to bind to fungal ergosterol instead of human cholesterol. ${ }^{55}$ For all these reasons the saponin scaffold may represent an opportunity to expand the available limited class of antifungal agents. The mode of action as well as their potential hemolytic and or cytotoxic effect must be investigated more in depth in order to take into account their bioavailability.

\section{Experimental}

\section{General experimental procedures}

UV spectra were measured on a PerkinElmer Lambda 20 spectrophotometer. LC-PDA-MS data were obtained with an Agilent 1100 series system (Santa Clara, CA, USA) consisting of an auto sampler, a high-pressure mixing pump and a PDA detector connected to a Finnigan MAT LCQ ion trap mass spectrometer equipped with a Finnigan electrospray (ESI) interface (San Jose, CA, USA). HRESIMS data were obtained on a MicromassLCT Premier Time of Flight (TOF) mass spectrometer (Waters, MA, USA) with an electrospray interface. ${ }^{1} \mathrm{H}$ and ${ }^{13} \mathrm{C}$ NMR data were recorded on a Varian Inova 500 spectrometer (Palo Alto, CA, USA) (499.87 and 125.70 MHz, respectively) in DMSO- $d_{6}$ with TMS as an internal standard. Complete assignment was performed using 2D experiments such as gradient COSY (correlation spectroscopy), gradient HSQC (heteronuclear single quantum correlation spectroscopy), gradient HMBC (heteronuclear multiple bond correlation spectroscopy) and NOESY (nuclear Overhauser effect spectroscopy)). UHPLC-TOF-HRMS analysis of the isolated compounds was performed according to standard procedures. ${ }^{56}$ Analytical HPLC was carried out on an HP 1100 system equipped with a photodiode array detector (Agilent Technologies, Santa Clara, CA, USA). The standard of compound 5 (hederagenin, $>90 \%$, cas. 465-99-6) was obtained from Extrasynthese, Genay, France. Compound $\mathbf{6}$ (3- $\beta$-D-glucose medicagenic acid, $>95 \%$, cas. 49792-23-6) was obtained from the Phytochemistry and Bioactive Natural Products database, University of Geneva. Standard of compound 7 (medicagenic acid, > 95\%, cas. 599-07-5) was obtained from Phytolab, Vestenbergsgreuth, Germany.

\section{Plant material}

All the plant material was collected in the Panama Channel Zone, Panama, and identified by De Gracia, J. The steams of Conostegia speciosa Naudin were collected in August 1991, at Carretera Llano Cartí. The leaves of Odontadenia puncticulosa (Rich.) Pulle were collected in March 1992, at Cerro Azul, La Eneida. The leaves of Schefflera systila (Donn. Sm.) R. Vig. were collected in July 2001, at Parque Nacional Altos de Campana. A voucher of each species was deposited at the National Herbarium of Panama (FLORPAN (No. 1673, 0705 and 5223, respectively)) and at the Phytochemistry \& Bioactive Natural Products and Pharmacognosy Laboratory, University of Geneva, Switzerland (No. 7715, 6317 and 8275 , respectively).

\section{Preparation of the crude extracts}

The air-dried plant material was pulverized in a Wiley Mill and extracted at room temperature successively with dichloromethane $\left(\mathrm{CH}_{2} \mathrm{Cl}_{2}\right)$ and methanol $(\mathrm{MeOH})$. The extracts were concentrated under pressure and later lyophilized. From $580 \mathrm{~g}$ of $S$. systila leaves, $18.8 \mathrm{~g}$ of $\mathrm{CH}_{2} \mathrm{Cl}_{2}$ extract and $65 \mathrm{~g}$ of $\mathrm{MeOH}$ extract were obtained. From $500 \mathrm{~g}$ of $O$. puncticulosa leaves, $14 \mathrm{~g}$ of $\mathrm{CH}_{2} \mathrm{Cl}_{2}$ extract and $78 \mathrm{~g}$ of $\mathrm{MeOH}$ extract were obtained. From $32.5 \mathrm{~g}$ of C. speciosa stems, $1.4 \mathrm{~g}$ of $\mathrm{CH}_{2} \mathrm{Cl}_{2}$ extract and $5 \mathrm{~g}$ of $\mathrm{MeOH}$ extract were obtained. 
HPTLC analysis

The HPTLC analyses were performed with an Automatic TLC Sampler (4) and an Automatic Developing Chamber (ADC 2) (CAMAG, Muttenz, Switzerland). Plant extract $(200 \mu \mathrm{g})$ was deposited onto the HPTLC plate $(10 \times 10 \mathrm{~cm}$, silica gel 60 , Merck, Darmstadt, Germany). Methanolic extract of $O$. puncticulosa was eluted with the solvent system $\mathrm{CH}_{2} \mathrm{Cl}_{2} / \mathrm{MeOH} /$ ethyl acetate (EtOAc) 87:12:1. C. speciosa were eluted with $\mathrm{CH}_{2} \mathrm{Cl}_{2} / \mathrm{MeOH} / \mathrm{EtOAc} 70: 15: 15$. The methanolic extract of S. systila was eluted with $\mathrm{CH}_{2} \mathrm{Cl}_{2} / \mathrm{MeOH} / \mathrm{EtOAc}$ 50:30:20. TLC profiles were revealed by ultraviolet (UV) detection at 254 and $366 \mathrm{~nm}$ with a TLC Visualizer (CAMAG), and images were obtained with visionCATS version 1.4.0 software. The HPTLC analyses were performed in duplicate for the bioautography and for the chemical detection with specific reagents.

Semi preparative HPLC-microfractionation for the antifungal assay and isolation of the major antifungal compounds

$200 \mu \mathrm{L}$ of each extract were injected in a semi preparative HPLC (Spotprep Liquid Chromatography, Armen instrument) with an $\mathrm{X}$-Bridge $\mathrm{C}_{18}$ column $(250 \times 10 \mathrm{~mm}$ i.d.; $5 \mu \mathrm{m}$, Waters $)$ for the fractionation of the methanolic extracts of $S$. systyla and $O$. puncticulosa, while the extract of $C$. speciosa was fractionated with a $\mathrm{X}$-Bridge $\mathrm{C}_{18}$ column $(150 \times 19 \mathrm{~mm}$ i.d.; $5 \mu \mathrm{m}$, Waters $)$. Fractions were collected every $10 \mathrm{~mL}$. After collection, each fraction was evaporated to dryness using a SpeedVac (HT-4X Genevac ${ }^{\circledR}$, Stone Ridge, NY, USA). The dried fractions were evaluated in the bioautography antifungal assay. The methanolic extract of $S$. systyla leaves $(25 \mathrm{mg})$ was eluted with a flow rate of $4.7 \mathrm{~mL} \mathrm{~min}^{-1}$ with the following solvent system: $\mathrm{A}=\mathrm{H}_{2} \mathrm{O}$ with $0.1 \%$ formic acid (FA), $\mathrm{B}=\mathrm{MeOH}$ with $0.1 \% \mathrm{FA}$; gradient: 5 to $100 \% \mathrm{~B}$ from $0-60 \mathrm{~min}$. The detection was performed at $280 \mathrm{~nm}$. The active fractions 30-32 yielded compound $\mathbf{1}(2.1 \mathrm{mg})$. The methanolic extract of $O$. puncticulosa stems (45 mg) was eluted with a flow rate of $14 \mathrm{~mL} \mathrm{~min}^{-1}$ with the following solvent system: $\mathrm{A}=\mathrm{H}_{2} \mathrm{O}$ with $0.1 \% \mathrm{FA}, \mathrm{B}=\mathrm{MeOH}$ with $0.1 \% \mathrm{FA}$; gradient: 2 to $45 \% \mathrm{~B}$ from $0-25 \mathrm{~min}$, then to 45 to $100 \% \mathrm{~B}$ from $25-31 \mathrm{~min}, 100 \% \mathrm{~B}$ between $31-40 \mathrm{~min}$. The detection was performed at $254 \mathrm{~nm}$. The active fraction 54 yielded compound 2 (4.3 mg). The methanolic extract of C. speciosa stems $(38.65 \mathrm{mg})$ was eluted with a flow rate of $4.7 \mathrm{~mL} \mathrm{~min}{ }^{-1}$ with the following solvent system: $\mathrm{A}=\mathrm{H}_{2} \mathrm{O}$ with $0.1 \% \mathrm{FA}, \mathrm{B}=\mathrm{MeOH}$ with $0.1 \% \mathrm{FA}$; gradient: 5 to $100 \%$ $\mathrm{B}$ from 0-80 min. The detection was performed at $254 \mathrm{~nm}$. The active fraction 35 yielded compound 4 ( $2.5 \mathrm{mg})$.
Isolation of the antifungal compounds from the methanolic extract of $O$. puncticulosa using medium pressure liquid chromatography (MPLC-UV)

The MeOH (5 g) extract of $O$. puncticulosa was fractionated using MPLC with a $\mathrm{C}_{18}$ reverse stationary phase (Zeoprep ${ }^{\circledR}$ 60, 15-25 um, (Zeochem, Uetikon am See, Switzerland) column (460 × 70 mm, i.d.; Buchï, Flawil, Switzerland) with a linear gradient $\mathrm{MeOH}$ and $\mathrm{H}_{2} \mathrm{O}$ from 5 to $100 \% \mathrm{MeOH}$ with $0.1 \%$ formic acid at a flow rate of $6 \mathrm{~mL} \mathrm{~min}^{-1}$ yielded 31 fractions. Fractions F28 yielded compound 2 (33.8 mg), while F30 yielded compound 3 (127.4 mg).

Identification of the isolated compounds

$(\alpha)$-Hederin (1)

Amorphous powder; HR-ESI-MS m/z: 749.4447 $[\mathrm{M}-\mathrm{H}]^{+}$(calcd. for $\mathrm{C}_{41} \mathrm{H}_{65} \mathrm{O}_{12}: 749.4476, \Delta=3.9 \mathrm{ppm}$ ). For the ${ }^{1} \mathrm{H}$ and ${ }^{13} \mathrm{C}$ NMR, see Supplementary Information, Shao et al. ${ }^{57}$ and Panov et al. ${ }^{58}$

\section{Pulsatilla saponin D (2)}

Amorphous powder; HR-ESI-MS m/z: 913.5292 $[\mathrm{M}+\mathrm{H}]^{+}$(calcd. for $\mathrm{C}_{47} \mathrm{H}_{77} \mathrm{O}_{17}: 912.51362, \Delta=3.4 \mathrm{ppm}$ ). For the ${ }^{1} \mathrm{H}$ and ${ }^{13} \mathrm{C}$ NMR, see Supplementary Information and Bang et al. ${ }^{59}$

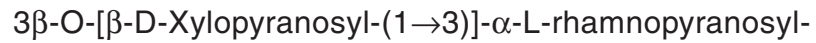
$(1 \rightarrow 2)$-[ $\beta$-D-glucopyranosyl- $(1 \rightarrow 4)]-\alpha$-L-arabinopyranosylhederagenin (3)

Amorphous powder; HR-ESI-MS m/z: 1045.5612 $[\mathrm{M}+\mathrm{H}]^{+}$(calcd. for $\mathrm{C}_{52} \mathrm{H}_{85} \mathrm{O}_{21}: 1044.5539, \Delta=2.8 \mathrm{ppm}$ ). For the ${ }^{1} \mathrm{H}$ and ${ }^{13} \mathrm{C}$ NMR, see Supplementary Information and Wang et al. ${ }^{31}$

Arjunolic acid (4)

Amorphous powder; HR-ESI-MS m/z: 487.3419 $[\mathrm{M}-\mathrm{H}]^{+}$(calcd. for $\mathrm{C}_{30} \mathrm{H}_{47} \mathrm{O}_{5}: 487.3424, \Delta=1 \mathrm{ppm}$ ). For the ${ }^{1} \mathrm{H}$ and ${ }^{13} \mathrm{C}$ NMR, see Supplementary Information and Ghosh et al. ${ }^{60}$

Yeast strains

The strains used in the study are: C. albicans DSY2621, ${ }^{61}$ C. albicans CAF2.1, C. krusei ATCC 6258, C. tropicalis ATCC 75, C. parapsilosis ATCC 22019, C. glabrata DSY562. ${ }^{62}$

\section{Bioautography}

The assay used was an optimized version of a method 
published by Rahalison et al..$^{63}$ Briefly, the C. albicans strains were cultivated overnight at $36{ }^{\circ} \mathrm{C}$ in Sabouraud broth medium. A dilution was made in order to obtain an inoculum of $10^{5}$ cells $\mathrm{mL}^{-1}$ (an optical density (OD) equal to 1 at $630 \mathrm{~nm}$ corresponding to approximately $10^{7}$ cells $\mathrm{mL}^{-1}$ ) in malt agar (malt extract, $30.0 \mathrm{~g} \mathrm{~L}^{-1}$; peptone from soymeal, $3.0 \mathrm{~g} \mathrm{~L}^{-1}$; agar-agar, $15.0 \mathrm{~g} \mathrm{~L}^{-1}$; Merck). The molten medium was maintained in a water bath at $45^{\circ} \mathrm{C}$. The OD at $630 \mathrm{~nm}$ of the $C$. albicans culture was measured with an UV-Vis spectrophotometer (Synergy H1, Biotek, equipped with the software Gen 5.2 software). Approximately $20 \mathrm{~mL}$ of the inoculum (either DSY2621 or CAF2-1) were distributed rapidly over the HPTLC plate with a sterile pipet. After solidification of the medium, the plates were incubated overnight at $36{ }^{\circ} \mathrm{C}$ in polyethylene boxes lined with moist chromatography paper. The bioautograms were sprayed with an aqueous solution $\left(2.5 \mathrm{mg} \mathrm{mL}^{-1}\right)$ of thiazolyl blue (methyl thiazolyl tetrazolium chloride; MTT; Fluka), and incubated for $6 \mathrm{~h}$ at $36^{\circ} \mathrm{C}$. Clear inhibition zones were observed against a purple background. To calculate the MIQ, $10 \mu \mathrm{L}$ aliquots of different concentrations (from 0.01 to $10 \mathrm{mg} \mathrm{mL}^{-1}$ in $\mathrm{MeOH}$ ) of the pure compounds were spotted manually on the HPTLC plate as well as $10 \mu \mathrm{L}$ of only $\mathrm{MeOH}$. Then, the HPTLC plate without elution was submitted to the same procedure published by Favre-Godal et al. ${ }^{13}$ The MIQ was defined as the test compound quantity at which inhibition was observed.

\section{Antifungal susceptibility testing}

Antifungal susceptibility testing on planktonic cells was carried out on the basis of EUCAST protocols with slight modifications. ${ }^{64}$ Briefly, C. albicans strains were cultivated overnight at $30{ }^{\circ} \mathrm{C}$ under constant agitation in yeast extract peptone dextrose (YEPD). Cultures were diluted to a density of $0.5-2 \times 10^{5}$ cells $\mathrm{mL}^{-1}$ in Roswell Park Memorial Institute (RPMI) 1640 medium (Sigma) with L-glutamine, without bicarbonate, and with phenol red as the pH indicator. RPMI 1640 medium was buffered to $\mathrm{pH} 7$ with $0.165 \mathrm{M}$ morpholinepropanesulfonic acid (MOPS) and was supplemented with glucose to a final concentration $(\mathrm{m} / \mathrm{v})$ of $2 \%$ and with $1 \%$ dimethyl sulfoxide (DMSO). Compounds were dissolved in DMSO to $1 \mathrm{mg} \mathrm{mL}^{-1}$ as final concentration. First, $50 \mu \mathrm{L}$ of RPMI was distributed on each well of the 96-well plate. Two-fold serial dilutions were prepared from 32 to $0.0162 \mu \mathrm{g} \mathrm{mL} \mathrm{m}^{-1}$. Since the yeast inoculum was fixed at a volume of $150 \mu \mathrm{L}$ with a density of $2 \times 10^{5}$ cells $\mathrm{mL}^{-1}$, $50 \mu \mathrm{L}$ of an eight-fold concentrated compound stock was first dispensed to the well corresponding to the highest drug concentration. Two-fold dilutions were next performed by serially transferring half volumes of each well up to the last well of the microplate row. Finally, $150 \mu \mathrm{L}$ of the yeast inoculum were added to each well. Drug-free cultures and sterility controls were included in each 96-well plate. Plates were incubated at $35^{\circ} \mathrm{C}$ for $24 \mathrm{~h}$ and then MICs were read with a spectrophotometer plate reader set at $450 \mathrm{~nm}$. The MIC was defined as the drug concentration at which the optical density was equal or decreased more than $50 \%$ from that of the drug-free culture. Antifungal susceptibility assays on biofilms were conducted according to a published protocol. ${ }^{36}$ Briefly, an aliquot of a $100 \mu \mathrm{L}$ solution $\left(1 \times 10^{6}\right.$ cells $\mathrm{mL}^{-1}$ density $)$ per well prepared in the RPMI medium $0.2 \%$ glucose $(\mathrm{pH} 7)$ was deposited in a 96 well plate and incubated at $37{ }^{\circ} \mathrm{C}$ for $48 \mathrm{~h}$ to allow biofilm formation. Wells were then washed twice with phosphate-buffered saline (PBS). Two-fold serial dilutions of the compounds were prepared from 50 to $1.56 \mu \mathrm{g} \mathrm{mL}^{-1}$ and added to the wells containing the biofilms. Plates were incubated again for $48 \mathrm{~h}$ at $37^{\circ} \mathrm{C}$ and then washed twice with PBS. A measurement of the metabolic activity of the sessile cells was performed using a colorimetric assay with $2 H$-tetrazolium,2,3bis(2-methoxy-4-nitro-5-sulfophenyl)-5-[(phenylamino) carbonyl]-hydroxide salt (XTT) (X4626, Sigma Aldrich). Plates were read with a spectrophotometer plate reader set at $492 \mathrm{~nm}$. The MIC was defined as the drug concentration at which the optical density value was equal or less than $50 \%$ of the one of the drug-free biofilm.

\section{Electron microscopy}

The $C$. albicans CAF2-1 strain was grown in $10 \mathrm{~mL}$ YNB liquid cultures ( $50 \mathrm{~mL}$ plastic tubes, $37^{\circ} \mathrm{C}, 2 \mathrm{~h}$ ). At this time, pulsatilla saponine D (2) and medicagenic acid 3-O- $\beta$-D-glucopyranoside (6) were added at a concentration of respectively 8 and $2 \mu \mathrm{g} \mathrm{mL}^{-1}$ in DMSO and the cultures were grown for $18 \mathrm{~h}$ to evaluate their cytotoxic effect. The samples were centrifuged $(10 \mathrm{~min}, 1300 \times \mathrm{g}$, room temperature), the supernatant was discarded, and the resulting pellet was prepared according to Roland and Vian. ${ }^{65}$ Briefly, the pellets were prefixed with a solution of $3 \%$ glutaraldehyde- $2 \%$ paraformaldehyde in $0.07 \mathrm{M}$ phosphate buffer ( $\mathrm{pH} 7$ ), embedded in $2 \%$ agarose and postfixed with a solution of $1 \% \mathrm{OsO}_{4}$. They were then dehydrated in a graded series of ethanol solutions [30-50-70-95-100\% (v/v)] and embedded in LR white resin (14381-UC; London Resin Company). After polymerization for $24 \mathrm{~h}$ at $60{ }^{\circ} \mathrm{C}$, thin $(0.08 \mu \mathrm{m})$ sections were cut and stained with a $2 \%$ uranyl acetate followed by lead citrate according to Reynolds. ${ }^{66}$ The thin sections were observed with a transmission electron microscope 
(Philips CM10) equipped with a Mega View II camera. Controls were performed in the same way without or with DMSO alone.

In vivo assay with Galleria mellonella larvae infected with C. albicans

Prior to the experiment, Galleria mellonella larvae (0.35-0.4 g; home reared) were kept in plastic boxes at $14^{\circ} \mathrm{C}$ in the dark. C. albicans CAF2-1 was grown overnight in YEPD, washed twice and suspended in phosphatebuffered saline (PBS). The cell cultures were diluted in PBS (supplemented with $200 \mathrm{mg} \mathrm{L}^{-1}$ ampicillin) to achieve an inoculum of $7.5 \times 10^{5}$ cells per larva. Natural product (NP), fluconazole or yeast inoculum was injected into the larval haemocoel through the last pro-leg using a disposable syringe (1 mL Myjector U-100 29G syringe; Terumo, Somerset, NJ). The pro-leg was previously cleaned with $70 \%$ ethanol. The larvae were first infected with $C$. albicans, and after $1 \mathrm{~h}$, they received the NPs or the drug (10 $\mu \mathrm{L}$ per injection). The larvae were then incubated in petri dishes at $30^{\circ} \mathrm{C}$ in the darkness for 8 days. Larval death was monitored daily based on lack of response to touching with a pipette tip. For each condition, a total of 15 larvae were used, and each experiment was replicated three times.

\section{Supplementary Information}

Supplementary information (representation of the isolation process of antifungal saponins from Odontadenia puncticulosa and Conostegia speciosa and 1D and 2D NMR spectra) is available free of charge at http://jbcs.sbq.org.br.

\section{Acknowledgments}

The authors are thankful to the Swiss National Science Foundation for providing financial support for this project, which aims to identify new antifungal compounds of natural origin (Grant No. CR2313_143733 to J. L. W., E. F. Q., D. S. and K. G.), and are thankful to Mrs Emilie Michellod for her very helpful technical assistance in TEM experiments.

\section{References}

1. Ostrosky-Zeichner, L.; Casadevall, A.; Galgiani, J. N.; Odds, F. C.; Rex, J. H.; Nat. Rev. Drug Discov. 2010, 9, 719.

2. Denning, D. W.; Perlin, D. S.; Future Microbiol. 2011, 6, 1229.

3. Lim, C. S.; Rosli, R.; Seow, H. F.; Chong, P. P.; Eur. J. Clin. Microbiol. Infect. Dis. 2012, 31, 21.

4. Beyda, N. D.; Lewis, R. E.; Garey, K. W.; Ann. Pharmacother. 2012, 46, 1086.
5. Perlin, D. S.; Drugs 2014, 74, 1573.

6. Bitar, D.; Lortholary, O.; Dromer, F.; Coignard, B.; Che, D.; Alanio, A.; Bretagne, S.; Grenouillet, F.; Hénon, T.; Kaiser, J.-D.; Limat, S.; Millon, L.; Leroy, J.; Gangneux, J.-P.; Sitbon, K.; Lebeau, B.; Thiébaut, A.; Strat, Y. L.; Renaudat, C.; Desnos-Ollivier, M.; Fontanet, A.; Bulletin Épidémiologique Hebdomadaire, Numéro Thématique - Mycoses Invasives en France: Épidémiologie, Enjeux Diagnostiques et Thérapeutiques; Institut de Veillle Sanitaire: Institut de Veille Sanitaire: Saint-Maurice, France, 2013.

7. Pappas, P. G.; Rex, J. H.; Sobel, J. D.; Filler, S. G.; Dismukes, W. E.; Walsh, T. J.; Edwards, J. E.; Clin. Infect. Dis. 2004, 38, 161.

8. LaFleur, M. D.; Kumamoto, C. A.; Lewis, K.; Antimicrob. Agents Chemother. 2006, 50, 3839.

9. Rasmussen, T. B.; Givskov, M.; Int. J. Med. Microbiol. 2006, 296, 149.

10. Pfaller, M. A.; Am. J. Med. 2012, 125, S3.

11. Arif, T.; Bhosale, J. D.; Kumar, N.; Mandal, T. K.; Bendre, R. S.; Lavekar, G. S.; Dabur, R.; J. Asian Nat. Prod. Res. 2009, 11,621 .

12. Favre-Godal, Q.; Queiroz, E. F.; Wolfender, J. L.; J. AOAC Int. 2013, 96, 1175.

13. Favre-Godal, Q.; Dorsaz, S.; Queiroz, E. F.; Conan, C.; Marcourt, L.; Wardojo, B. P. E.; Voinesco, F.; Buchwalder, A.; Gindro, K.; Sanglard, D.; Wolfender, J. L.; Phytochemistry 2014, 105, 68.

14. Plunkett, G. M.; Lowry, P. P.; Frodin, D. G.; Wen, J.; Ann. Missouri Bot. Gard. 2005, 92, 202.

15. Li, Y.; But, P. P. H.; Ooi, V. E. C.; Antiviral Res. 2005, 68, 1.

16. Zhu, M.; Bowery, N. G.; Greengrass, P. M.; Phillipson, J. D.; J. Ethnopharmacol. 1996, 54, 153.

17. Morales, J. F.; Bull. Jard. Bot. Natl. Belg. 1999, 381-477, 381.

18. Breitbach, U. B.; Niehues, M.; Lopes, N. P.; Faria, J. E. Q.; Brandão, M. G. L.; J. Ethnopharmacol. 2013, 147, 180.

19. Coe, F. G.; Anderson, G. J.; J. Ethnopharmacol. 2005, 96, 303.

20. Joly, L. G.; Guerra, S.; Septimo, R.; Solis, P. N.; Correa, M. D.; Gupta, M. P.; Levy, S.; Sandberg, F.; Perera, P.; J. Ethnopharmacol. 1990, 28, 191.

21. Prakash Chaturvedula, V. S.; Schilling, J. K.; Wisse, J. H.; Miller, J. S.; Evans, R.; Kingston, D. G. I.; Magn. Reson. Chem. 2003, 41, 139.

22. Kriebel, R.; Phylogeny, Taxonomy and Morphological Evolution in Conostegia (Melastomataceae: Miconieae); CUNY Academic Works: New York, USA, 2014.

23. Guillarme, D.; Nguyen, D. T. T.; Rudaz, S.; Veuthey, J. L.; Eur. J. Pharm. Biopharm. 2008, 68, 430.

24. Guillarme, D.; Nguyen, D. T. T.; Rudaz, S.; Veuthey, J. L.; Eur. J. Pharm. Biopharm. 2007, 66, 475.

25. Guillarme, D.; Nguyen, D. T.; Rudaz, S.; Veuthey, J. L.; Eur. J. Pharm. Biopharm. 2008, 68, 430. 
26. Mshvildadze, V.; Elias, R.; Faure, R.; Debrauwer, L.; Dekanosidze, G.; Kemertelidze, E.; Balansard, G.; Chem. Pharm. Bull. 2001, 49, 752.

27. Kojima, H.; Ogura, H.; Phytochemistry 1989, 28, 1703.

28. King, F. E.; King, T. J.; Ross, J. M.; J. Chem. Soc. 1954, 3995.

29. Shimizu, M.; Shingyouchi, K.; Morita, N.; Kizu, H.; Tomimori, T.; Chem. Pharm. Bull. 1978, 26, 1666.

30. Challal, S.; Queiroz, E. F.; Kloeti, W.; Debrus, B.; Guillarme, D.; Wolfender, J. L.; Planta Med. 2015, 81, 1636.

31. Wang, X.-Y.; Chen, X.-L.; Tang, H.-F.; Gao, H.; Tian, X.-R.; Zhang, P.-H.; Planta Med. 2011, 77, 1550.

32. Lee, M. W.; Kim, S. U.; Hahn, D. R.; Biol. Pharm. Bull. 2001, 24,718 .

33. Ekabo, O. A.; Farnsworth, N. R.; Henderson, T. O.; Mao, G.; Mukherjee, R.; J. Nat. Prod. 1996, 59, 431.

34. Liu, M.; Katerere, D. R.; Gray, A. I.; Seidel, V.; Fitoterapia 2009, 80, 369.

35. Bink, A.; Pellens, K.; Cammue, B. P. A.; Thevissen, K.; Open Mycol. J. 2011, 5, 29.

36. Pierce, C. G.; Uppuluri, P.; Tristan, A. R.; Wormley Jr., F. L.; Mowat, E.; Ramage, G.; Lopez-Ribot, J. L.; Nat. Protoc. 2008, 3, 1494 .

37. Favel, A.; Steinmetz, M. D.; Regli, P.; Vidalollivier, E.; Elias, R.; Balansard, G.; Planta Med. 1994, 60, 50.

38. Lorent, J.; Le Duff, C. S.; Quetin-Leclercq, J.; MingeotLeclercq, M. P.; J. Biol. Chem. 2013, 288, 14000.

39. Oleszek, W.; Price, K. R.; Colquhoun, I. J.; Jurzysta, M.; Ploszynski, M.; Fenwick, G. R.; J. Agric. Food Chem. 1990, 38,1810 .

40. Martson, A.; Gafner, F.; Dossaji, S. F.; Hostettmann, K.; Phytochemistry 1988, 27, 1325.

41. Levy, M.; Zehavi, U.; Naim, M.; Polacheck, I.; J. Agric. Food Chem. 1986, 34, 960.

42. Polacheck, I.; Zehavi, U.; Naim, M.; Levy, M.; Evron, R.; Antimicrob. Agents Chemother. 1986, 30, 290.

43. Polacheck, I.; Levy, M.; Guizie, M.; Zehavi, U.; Naim, M.; Evron, R.; Zbl. Bakt-Int J. Med. M. 1991, 275, 504.

44. Avato, P.; Bucci, R.; Tava, A.; Vitali, C.; Rosato, A.; Bialy, Z.; Jurzysta, M.; Phytother. Res. 2006, 20, 454.

45. Augustin, J. M.; Kuzina, V.; Andersen, S. B.; Bak, S.; Phytochemistry 2011, 72, 435

46. Moulin-Traffort, J.; Favel, A.; Elias, R.; Regli, P.; Mycoses 1998, 41, 411.

47. Paparella, S.; Tava, A.; Avato, P.; Biazzi, E.; Macovei, A.; Biggiogera, M.; Carbonera, D.; Balestrazzi, A.; Phytochemistry 2015, 111, 114 .
48. Fallon, K. K. J. P.; Fungal Biol. Rev. 2010, 24, 79.

49. Brennan, M.; Thomas, D. Y.; Whiteway, M.; Kavanagh, K.; FEMS Immunol. Med. Mic. 2002, 34, 153.

50. Dinda, B.; Debnath, S.; Mohanta, B. C.; Harigaya, Y.; Chem. Biodiversity 2010, 7, 2327.

51. Prescott, T. A. K.; Rigby, L. P.; Veitch, N. C.; Simmonds, M. S. J.; Phytochemistry 2014, 101, 116.

52. Timon-David, P.; Julien, J.; Gasquet, M.; Balansard, G.; Bernard, P.; Ann. Pharm. Fr. 1980, 38, 545.

53. Yu, K.; Chen, F.; Li, C.; Curr. Drug Metab. 2012, 13, 577.

54. Hostettmann, K.; Maston, A.; Chemistry and Pharmacology of Natural Products; Saponins; Cambridge University Press: Cambridge, 1995.

55. Coleman, J. J.; Okoli, I.; Tegos, G. P.; Holson, E. B.; Wagner, F. F.; Hamblin, M. R.; Mylonakis, E.; ACS Chem. Biol. 2010, 5,321 .

56. Guillarme, D.; Ruta, J.; Rudaz, S.; Veuthey, J. L.; Anal. Bioanal. Chem. 2010, 397, 1069.

57. Shao, C. J.; Kasai, R.; Xu, J. D.; Tanaka, O.; Chem. Pharm. Bull. 1989, 37, 311.

58. Panov, D. A.; Grishkovets, V. I.; Kachala, V. V.; Shashkov, A. S.; Chem. Nat. Compd. 2006, 42, 49.

59. Bang, S.-C.; Lee, J.-H.; Song, G.-Y.; Kim, D.-H.; Yoon, M.-Y.; Ahn, B.-Z.; Chem. Pharm. Bull. 2005, 53, 1451.

60. Ghosh, J.; Das, J.; Manna, P.; Sil, P. C.; Free Radical Biol. Med. 2010, 48, 535.

61. Pascual, A.; Nieth, V.; Calandra, T.; Bille, J.; Bolay, S.; Decosterd, L. A.; Buclin, T.; Majcherczyk, P. A.; Sanglard, D.; Marchetti, O.; Antimicrob. Agents Chemother. 2007, 51, 137.

62. Sanglard, D.; Ischer, F.; Calabrese, D.; Majcherczyk, P. A.; Bille, J.; Antimicrob. Agents Chemother. 1999, 43, 2753.

63. Rahalison, L.; Hamburger, M.; Hostettmann, K.; Monod, M.; Frenk, E.; Phytochem. Anal. 1991, 2, 199.

64. Rodriguez-Tudela, J. L.; Arendrup, M. C.; Barchiesi, F.; Bille, J.; Chryssanthou, E.; Cuenca- Estrella, M.; Dannaoui, E.; Denning, D. W.; Donnely, J. P.; Dromer, F.; Fegeler, W.; Lass-Flörl, C.; Moore, C.; Richardson, M.; Sandve, P.; Velegraki, A.; Verweij, P.; Clin. Microbiol. Infect. 2008, 14, 398.

65. Roland, J.; Vian, B. In Electron Microscopy of Plant Cells; Hall, J. L.; Hawes, C., eds.; Academic Press: London, 1991, p. 1.

66. Reynolds, E. S.; J. Cell Biol. 1963, 17, 208.

Submitted: June 27, 2016

Published online: October 5, 2016 